\title{
Response and recovery dynamics of seagrasses Thalassia testudinum and Syringodium filiforme and macroalgae in experimental motor vessel disturbances
}

\author{
K. K. Hammerstrom ${ }^{1, *}$, W. J. Kenworthy ${ }^{2}$, P. E. Whitfield ${ }^{2}$, M. F. Merello ${ }^{3}$ \\ ${ }^{1}$ Moss Landing Marine Laboratories, 8272 Moss Landing Road, Moss Landing, California 95039, USA \\ ${ }^{2}$ Center for Coastal Fisheries and Habitat Research, NCCOS, NOS, NOAA, 101 Pivers Island Road, Beaufort, \\ North Carolina 28516, USA \\ ${ }^{3}$ Florida Fish and Wildlife Research Institute, 100 Eighth Avenue SE, St. Petersburg, Florida 33701, USA
}

\begin{abstract}
Shallow seagrass beds worldwide are being negatively impacted by human activities. Damage by boats includes anchor scars, propeller scars, and hull groundings. In some Thalassia testudinum-dominated systems, vessel damage may persist for years or decades, and even small scars may leave seagrass habitat susceptible to severe erosion by wind and wave-driven currents and storms. Cost-effective techniques for restoration in these erosion-prone systems must include sediment replacement and stabilization to best enhance seagrass recovery. We conducted 2 experiments to address the effects of excavation depth and sediment filling on seagrass and macroalgal recovery into small-scale disturbances such as propeller scars. Recovery in excavations $\geq 20 \mathrm{~cm}$ deep took 2 to $5 \mathrm{yr}$ longer than recovery in shallower disturbances $(10 \mathrm{~cm})$. Seagrasses were able to grow in native limestone fill material (diameter $0.6 \mathrm{~cm}$ ), although the compensatory response of Syringodium filiforme was dampened.
\end{abstract}

KEY WORDS: Seagrass · Restoration · Damage · Disturbance - Recovery $\cdot$ Thalassia testudinum • Syringodium filiforme

Resale or republication not permitted without written consent of the publishe

\section{INTRODUCTION}

Seagrass meadows are among the most valuable and productive ecosystems in the world (Costanza et al. 1997), but in many locations they are threatened by anthropogenic stressors such as watershed modification, commercial and residential development, and recreational and commercial motor vessel use (Sargent et al. 1995, Short \& Wyllie-Echeverria 1996, Duarte 2002). Direct and indirect human-mediated disturbance is now one of the most serious causes of seagrass loss worldwide (Short \& Wyllie-Echeverria 1996, Green \& Short 2003). Motor and sailing vessels are implicated in seagrass bed damage in a number of ways, including anchor and mooring damage (Walker et al. 1989, Hastings et al. 1995, Creed \& Filho 1999,
Milazzo et al. 2004), propeller scarring (Zieman 1976, Durako et al. 1992, Dawes et al. 1997, Dunton \& Schonberg 2002, Kenworthy et al. 2002; see our Fig. 1), and hull groundings (Whitfield et al. 2002, Fonseca et al. 2004). In 1995 it was estimated that over 12000 ha of seagrass beds in the Florida Keys National Marine Sanctuary (FKNMS) were moderately to severely scarred by boat propellers (Sargent et al. 1995). In a shallow seagrass-coral bank system north of the middle Florida Keys, vessel groundings accounted for 3 times more disturbances than propeller scars (Whitfield et al. 2002).

Motor vessel damage can vary in extent from shearing off of the aboveground canopy to excavation of belowground roots and rhizomes and underlying finegrained sediments, and is considered one of the most 


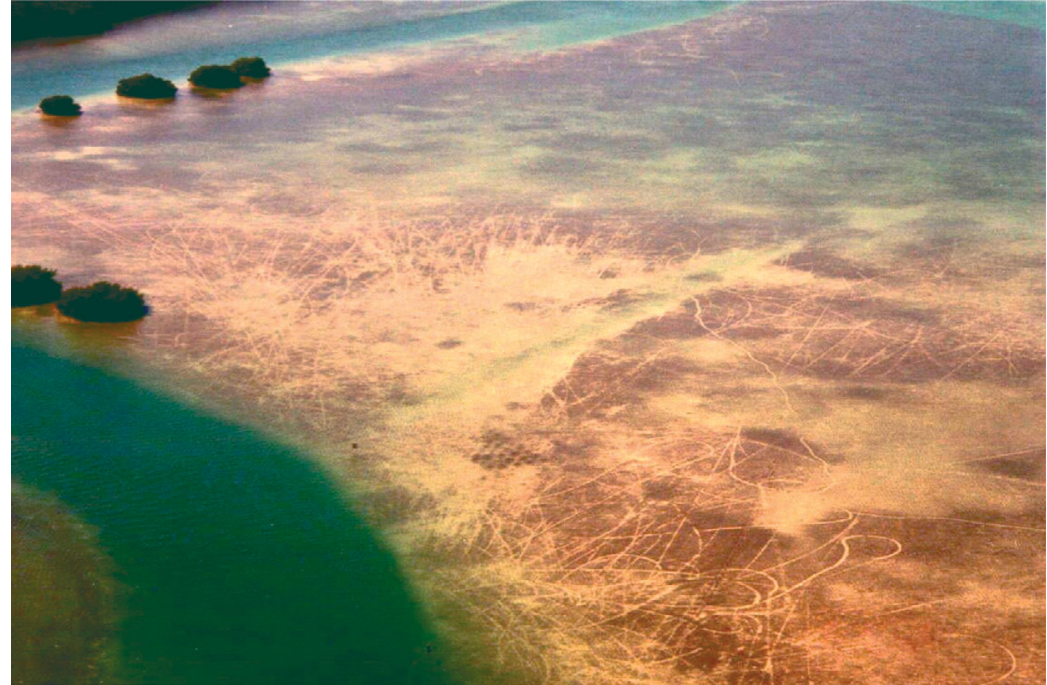

Fig. 1. Shallow seagrass bank severely scarred by boat propellers enhance the speed of recovery, planting early successional species and supplementing with fertilizer may be beneficial (Powell et al. 1991, Kenworthy \& Fonseca 1992, Fonseca et al. 1994, Kenworthy et al. 2000). In contrast, in high energy locations, the destabilized substrate must be restored by regrading, and further erosion must be prevented such that vegetative growth, seedling recruitment, and/or transplanting can take place.

Scar dimensions vary widely depending on the vessel creating the disturbance as well as the physical characteristics of the sediment underlying the seagrass bed (Kenworthy et al. 2002). The wide range of recovery times reported for propeller scars (2 to $26 \mathrm{yr}$, see Zieman 1976, Durako et al. 1992, severe disturbances that can occur in tropical seagrass meadows (Kenworthy et al. 2002). Anchor and mooring damage are often concentrated in areas subject to frequent recreational activity and result in a reduction in seagrass density and an increase in habitat fragmentation (Hastings et al. 1995, Creed \& Filho 1999, Milazzo et al. 2004). Propeller scarring may disrupt the belowground seagrass rhizome matrix as well as excavate sediments, leaving behind nearly sterile unvegetated trenches up to $50 \mathrm{~cm}$ deep, $50 \mathrm{~cm}$ wide, and hundreds of meters long (Kenworthy et al. 2002). Vessel hull groundings disturb intact seagrass habitat on a larger scale, excavating cavities or blowouts of unvegetated, exposed substrate that may be several meters deep and hundreds to thousands of square meters in area (Whitfield et al. 2002, Kirsch et al. 2005).

Once damage occurs, wind, wave, and currentinduced erosion may further enlarge all types of injuries by undercutting the seagrass at vulnerable scar margins, exacerbating disturbances that recover very slowly, if at all (Zieman 1976, Durako et al. 1992, Rodriguez et al. 1994, Hastings et al. 1995, Dawes et al. 1997, Prager \& Halley 1999, Kenworthy et al. 2002, Whitfield et al. 2002). Secondary damage by hurricanes to untreated disturbances in a high-energy environment may increase the disturbance footprint by more than $100 \%$ (Whitfield et al. 2002). Restoration of seagrass beds must therefore be tailored to the environmental conditions that prevail in the immediate area of the disturbance. In quiescent areas where erosion is not significant, the surrounding intact seagrasses may facilitate the sediment deposition necessary to fill shallow scars; eventually, vegetative growth from the disturbance margins, as well as sexual propagules, will fill in the unvegetated area. To
Dawes et al. 1997, Kenworthy et al. 2002) might be caused, in part, by differences in scar depth or the biophysical conditions within the scar (e.g. oxygen, substrate). Kenworthy et al. (2002) documented scars 2 to $4 \mathrm{~cm}$ in depth, while other estimates ranged from 3 to $12 \mathrm{~cm}$ (Durako et al. 1992, Uhrin \& Holmquist 2003). On shallow seagrass-coral banks in the middle Keys, we have observed propeller scars up to $50 \mathrm{~cm}$ deep and vessel hull groundings of less than $1 \mathrm{~m}$ to several meters deep (pers. obs.). Seagrass architecture and growth strategies may not allow the plants on the disturbance perimeter to effectively grow down into the bare substrate (Patriquin 1973), and the exposed apex material may be inhibited by light and subject to wave and current damage (Zieman 1976, Terrados 1997, Kenworthy et al. 2002). Furthermore, deeper disturbances often damage the seagrass root-rhizome matrix and expose unconsolidated sediment, which is most vulnerable to erosion.

Techniques for substrate stabilization for seagrass restoration have coupled artificial seagrass mats (Campbell \& Paling 2003) or plastic mesh (Van Keulen et al. 2003) with transplant units. Both techniques have met with limited success, yet stabilization may be crucial to preventing secondary damage caused by further erosion of vulnerable disturbance margins. Fill material for regrading scars must be heavy enough to resist erosion, yet sediments in seagrass beds are usually fine-grained, primarily sand and silt. To this end, we designed 2 experiments to examine the impact of boat-induced damage on seagrass recovery. Our first experiment tested the effect of excavation depth on seagrass recovery in simulated propeller scars. We created disturbances of 10,20 , and $40 \mathrm{~cm}$ depths and examined the change in scar depth, seagrass shoot 
density, and macroalgal cover as a function of time. Our second experiment tested the effect of filling on the recovery of seagrasses in simulated propeller scars. Using native limestone pea rock $(0.6$ to $0.7 \mathrm{~cm}$ diameter), we filled $30 \mathrm{~cm}$ deep excavations and compared their recovery to identically-sized, unfilled excavations. These 2 experiments addressed the following questions: (1) Does depth of excavation affect macrophyte recovery rate? (2) Does filling and regrading excavations affect macrophyte recovery rate?

\section{MATERIALS AND METHODS}

Site description. Two experiments were set up on a shallow seagrass-Porites sp. coral bank on the Gulf of Mexico side of Marathon Key in the FKNMS $\left(24.76^{\circ} \mathrm{N}\right.$, $81.16^{\circ} \mathrm{W}$, Fig. 2). This bank system, like many shallow seagrass systems in the Florida Keys and throughout the Caribbean, is raised 2 to $5 \mathrm{~m}$ above the surrounding bottom and was formed over several hundred years when the biotic communities physically stabilized a large volume of unconsolidated sediment. Water depth on the top of the bank ranges from $10-15 \mathrm{~cm}$ at low tide to $1-1.5 \mathrm{~m}$ at high tide. Temperatures range from $9-23^{\circ} \mathrm{C}$ in the winter months (December to February) to $28-34^{\circ} \mathrm{C}$ in the summer months (June to August). The bank-top community is dominated by Thalassia testudinum and Syringodium filiforme. In addition to these seagrasses, a diverse community of macroalgae thrives on the bank tops, forming an important component of the overall vegetated habitat.

Excavation experiment. The excavation experiment was initiated in June 2000. Experimental plots were laid out haphazardly in an area of approximately

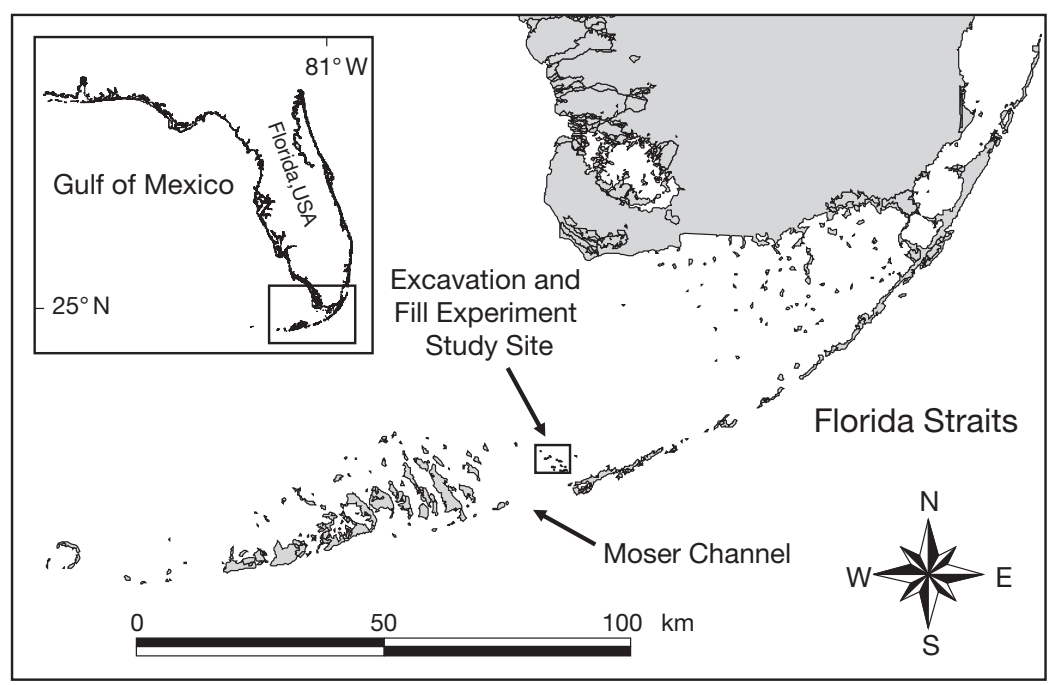

Fig. 2. Study site within the Florida Keys National Marine Sanctuary
$1200 \mathrm{~m}^{2}$ along a northwest-southeast axis, perpendicular to prevailing winds and parallel to tidal currents. Distances between plots ranged from 2 to $10 \mathrm{~m}$, and most plots were approximately $5 \mathrm{~m}$ apart. Plots were surveyed 8 times: September 2000, January, May, and September 2001, January and August 2002, May 2003, and April 2005.

Five replicates each of 4 excavation treatments ( $\mathrm{n}=$ 20 plots total) were deployed: (1) control (no sediment disturbance), (2) $10 \mathrm{~cm}$ excavation, (3) $20 \mathrm{~cm}$ excavation, and (4) $40 \mathrm{~cm}$ excavation. Plot dimensions measured $50 \mathrm{~cm} \times 150 \mathrm{~cm}$. Positions of the plots were marked with PVC poles and located with a differential global positioning system (DGPS). Control treatments were left undisturbed. The 3 other depth treatments were created by excavating above- and belowground biomass and sediments to the target depth using shovels and hoes.

Fill experiment. The fill experiment was conducted in September 2000 approximately $25 \mathrm{~m}$ east of the excavation experiment on the same bank. Experimental plots were laid out along a northwest-southeast axis in a $300 \mathrm{~m}^{2}$ area, arranged in a $3 \times 6$ array, and spaced 2 to $3 \mathrm{~m}$ apart. The experiment was surveyed 8 times: January, May, and September 2001, January, May, and August 2002, May 2003, and April 2005.

Six replicates of each of 3 fill treatments $(n=18$ plots total) were assigned to $50 \mathrm{~cm} \times 150 \mathrm{~cm}$ plots. The 3 treatments, randomly assigned within each row, included (1) control (no sediment disturbance), (2) fill, and (3) no fill. The fill and no-fill treatments were excavated to $30 \mathrm{~cm}$ depth as above. Fill treatments were filled with limestone pea rock (diameter approximately $0.6 \mathrm{~cm}$ ) until the sediment level was restored to grade, while no-fill treatments were left unfilled.

Data collection. During each survey period, we collected the following data in each experimental treatment: (1) short-shoot counts of each seagrass species, (2) cover of macroalgae, and (3) depth of excavation. Short shoots were counted inside 3 randomly placed $25 \mathrm{~cm} \times 25 \mathrm{~cm}$ quadrats in each plot. Macroalgal recovery was assessed using a modified Braun-Blanquet cover-abundance method to estimate cover (Fourqurean et al. 2001). Percent macroalgal cover was estimated in three $50 \mathrm{~cm} \times 50 \mathrm{~cm}$ quadrats in each plot (Table 1). Twelve depths were recorded from the center of each $25 \mathrm{~cm}$ $\times 25 \mathrm{~cm}$ subsection in each plot. Depth was measured to the bottom of the plot from a reference pole placed across the width of the plot and resting on the sur- 
Table 1. Braun-Blanquet cover-abundance scale. Cover is defined as the percentage of the bottom that is obscured by macroalgae when viewed by a diver from directly above

\begin{tabular}{|ll|}
\hline Value & Description \\
\hline 0 & Absent \\
0.1 & Solitary individual, less than 5\% cover \\
0.5 & Few individuals, less than 5\% cover \\
1 & Many individuals, less than 5\% cover \\
2 & 5 to $25 \%$ cover \\
3 & 25 to $50 \%$ cover \\
4 & 50 to $75 \%$ cover \\
5 & 75 to $100 \%$ cover \\
\hline
\end{tabular}

rounding intact seagrass bed. Replicate measurements from each experimental plot were averaged, and the mean plot value generated for each of these data types was used in further analysis.

Data analysis: excavation experiment. Thalassia testudinum and Syringodium filiforme shoot counts were square-root transformed to meet assumptions of variance homogeneity and residual normality. Shoot count data from 4 survey dates, chosen to roughly coincide with 1,2,3, and $5 \mathrm{yr}$ after deployment of the experiment (May 2001, August 2002, May 2003, April 2005), were analyzed by species. To avoid issues of non-independence, 1-way analysis of variance (ANOVA) was conducted on each date separately, and a Bonferroni correction was applied to the ANOVA $F$-test to account for repeated analyses (Underwood 1997). Tukey's Studentized range test was used to conduct pairwise comparisons among treatments when the overall ANOVA was significant at the $\alpha^{\prime}=$ 0.0125 level ( $\alpha=0.05$ corrected for 4 ANOVAs). Macroalgal cover data were treated similarly. For each survey date, a Kruskal-Wallis test was carried out on total macroalgal Braun-Blanquet values, followed by Bonferroni-corrected Wilcoxon rank sum tests for all pairwise comparisons when the Kruskal-Wallis test was significant at the $\alpha^{\prime}=0.0125$ level $(\alpha=0.05$ corrected for 4 ANOVAs).

Excavation experiment treatment depths were analyzed for 2 survey dates: May 2001 and August 2002. May 2001 data were natural-log transformed to meet assumptions of variance homogeneity and residual normality. While transformation failed to resolve residual non-normality for August 2002 data, untransformed variances were homogeneous. One-way ANOVA was conducted on transformed May 2001 data, and a Kruskal-Wallis test was conducted on untransformed August 2002 data. Tukey's Studentized range test was used to conduct pairwise comparisons among treatments when the overall ANOVA was significant at the $\alpha^{\prime}=0.025$ level (Bonferroni correction applied for 2 ANOVAs).
Data analysis: fill experiment. Syringodium filiforme shoot counts were square-root transformed to meet assumptions of variance homogeneity and residual normality. Transformation was not necessary for Thalassia testudinum shoot counts. Shoot count data from 4 survey dates (May 2001, May 2002, May 2003, April 2005), chosen to roughly coincide with 1, 2, 3, and $5 \mathrm{yr}$ after initiation of the experiment, were analyzed by species. Analyses and corrections were applied as above. Kruskal-Wallis tests (Bonferroni correction applied for 3 ANOVAs) and Bonferronicorrected Wilcoxon rank sum tests were also carried out on total macroalgal Braun-Blanquet values for 3 survey dates (May 2001, May 2003, April 2005) as above.

No transformation was necessary for fill experiment treatment depths to meet assumptions of variance homogeneity and residual normality. Depths were analyzed for 2 survey dates, September 2001 and August 2002, roughly 1 and 2 yr after deployment. Analyses and corrections were conducted as in the excavation experiment depth analyses.

\section{RESULTS}

\section{Excavation experiment}

Thalassia testudinum short-shoot counts for all survey dates are shown in Fig. 3. Short-shoot counts were significantly affected by treatment in May 2001 and August 2002 (Table 2). On both survey dates, there were no differences between the control and $10 \mathrm{~cm}$ treatment shoot counts, but both were significantly greater than the 20 and $40 \mathrm{~cm}$ treatments, which were not different from each other (Fig. 3). By May 2003, almost $3 \mathrm{yr}(1077 \mathrm{~d})$ after the onset of the experiment, there were no longer any significant differences in shoot counts among the 4 treatments (Table 2, Fig. 3). In April 2005, almost 5 yr after the initial disturbance, T. testudinum shoot counts were higher than in previous surveys, but were not different among treatments (Table 2, Fig. 3). The $10 \mathrm{~cm}$ treatments showed a rapid increase in shoot counts following initiation of the experiment. The 20 and $40 \mathrm{~cm}$ treatment shoot counts continued to be significantly lower than $10 \mathrm{~cm}$ treatments and controls through August 2002, 780 d after deployment (Fig. 3). In April 2005, shoot densities ranged from 318.9 to 469.3 shoots $\mathrm{m}^{-2}$, with an overall mean in control treatments for all survey periods of 250.4 short shoots $\mathrm{m}^{-2}$.

The recovery pattern of Syringodium filiforme differed from that of Thalassia testudinum, with $10 \mathrm{~cm}$ treatments returning quickly to pre-disturbance conditions, while 20 and $40 \mathrm{~cm}$ treatments responded by exceeding pre-disturbance shoot density 2 yr after the 

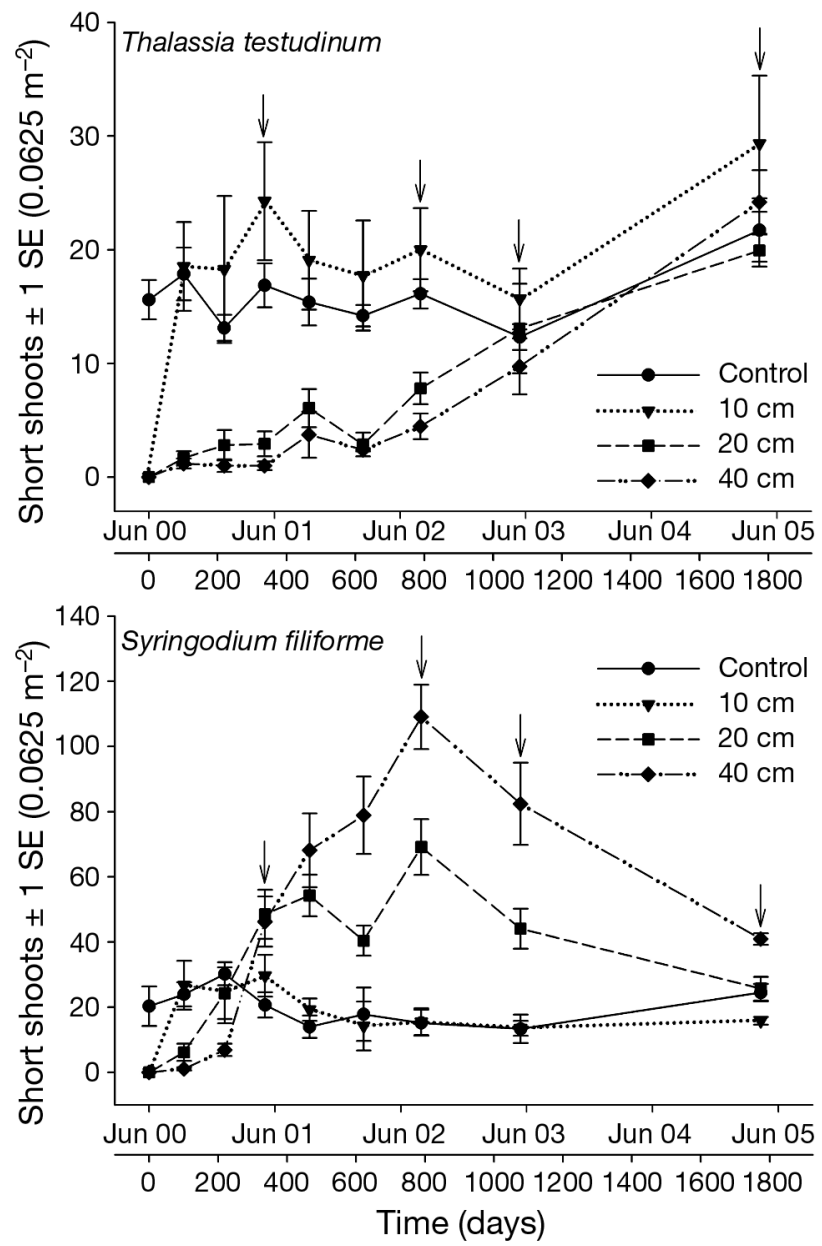

Fig. 3. Excavation experiment. Mean Thalassia testudinum and Syringodium filiforme shoot counts $( \pm 1 \mathrm{SE})$ for all surveys. Survey dates selected for data analysis are indicated by arrows. $\mathrm{N}=5$ replicates per treatment

Table 2. ANOVA results for excavation experiment shoot counts and algal cover. ANOVA $F$ (seagrass) and Kruskal-Wallis chi-square tests (algae) significant at the $\alpha=0.0125$ level are indicated by asterisks. SQRT TT and SQRT SF: squareroot transformed Thalassia testudinum and Syringodium filiforme shoot counts, respectively, in $0.0625 \mathrm{~m}^{2}$ quadrats; TMA: total macroalgal cover. Pairwise comparisons results are indicated in the right half of the table. Treatments with the same letter are not significantly different

\begin{tabular}{|c|c|c|c|c|c|c|c|}
\hline \multirow{2}{*}{$\begin{array}{l}\text { Dependent } \\
\text { variable }\end{array}$} & \multirow[t]{2}{*}{ Date } & \multirow{2}{*}{$\begin{array}{l}F / \chi^{2}- \\
\text { value }\end{array}$} & \multirow[t]{2}{*}{ p-value } & \multicolumn{4}{|c|}{ Pairwise comparisons } \\
\hline & & & & Control & $10 \mathrm{~cm}$ & $20 \mathrm{~cm}$ & $40 \mathrm{~cm}$ \\
\hline \multirow[t]{4}{*}{ SQRT TT } & May 2001 & 27.58 & $<0.0001^{*}$ & A & A & B & B \\
\hline & Aug 2002 & 15.03 & $<0.0001^{*}$ & $\mathrm{~A}$ & A & B & B \\
\hline & May 2003 & 1.01 & 0.4131 & $\mathrm{~A}$ & A & $\mathrm{A}$ & A \\
\hline & Apr 2005 & 1.09 & 0.3828 & A & A & A & A \\
\hline \multirow[t]{4}{*}{ SQRT SF } & May 2001 & 3.97 & 0.0273 & $\mathrm{~A}$ & $\mathrm{AB}$ & B & $\mathrm{AB}$ \\
\hline & Aug 2002 & 36.79 & $<0.0001^{*}$ & A & $\mathrm{A}$ & B & B \\
\hline & May 2003 & 24.70 & $<0.0001^{*}$ & A & A & B & $\mathrm{C}$ \\
\hline & Apr 2005 & 15.96 & $<0.0001^{*}$ & $\mathrm{~A}$ & B & $\mathrm{A}$ & $\mathrm{C}$ \\
\hline \multirow[t]{4}{*}{ TMA } & May 2001 & 16.37 & $0.001^{*}$ & A & A & $\mathrm{A}$ & A \\
\hline & Aug 2002 & 12.61 & $0.0056^{*}$ & A & $\mathrm{AB}$ & B & $\mathrm{AB}$ \\
\hline & May 2003 & 14.26 & $0.0026^{*}$ & $\mathrm{~A}$ & $\mathrm{~A}$ & $\mathrm{AB}$ & $\mathrm{B}$ \\
\hline & Apr 2005 & 12.50 & $0.0058^{*}$ & A & A & $\mathrm{AB}$ & B \\
\hline
\end{tabular}

disturbance (Fig. 3). In May 2001, 11 mo after deployment, $20 \mathrm{~cm} S$. filiforme shoot counts were significantly different than controls, but no other comparisons were different (Table 2, Fig. 3). In August 2002, 20 and $40 \mathrm{~cm}$ treatment shoot counts did not differ from each other and were significantly greater than counts in $10 \mathrm{~cm}$ and control treatments. By May 2003, although counts in the 2 deepest depth treatments had dropped, they were still 2 to 4 times greater than $10 \mathrm{~cm}$ and control counts, and were significantly different from each other (Fig. 3). In April 2005, nearly 5 yr after the experiment was initiated, shoot counts in the $40 \mathrm{~cm}$ treatment were still significantly greater than those in all other treatments (Table 2, Fig. 3). Unlike T. testudinum, $S$. filiforme in the deepest treatments showed a compensatory recovery in which counts began to increase in the first year after deployment and were still significantly higher than controls almost $3 \mathrm{yr}$ (1095 d) later (Fig. 3). By May 2003, the shoot counts in 20 and $40 \mathrm{~cm}$ treatments had begun to decline. In April 2005, $20 \mathrm{~cm}$ treatment $S$. filiforme shoot counts no longer significantly differed from controls; however, $40 \mathrm{~cm}$ counts were still significantly elevated (Fig. 3). Interestingly, $10 \mathrm{~cm}$ counts were significantly lower than all other treatments, although values stayed relatively constant from August 2002 to April 2005 (Fig. 3). Control S. filiforme shoot counts ranged from 213.3 (May 2001) to $483.2 \mathrm{~m}^{-2}$ (January 2001) during the study, with a mean of 346 shoots $\mathrm{m}^{-2}$. The maximum density was 1745.1 shoots $\mathrm{m}^{-2}$ in the $40 \mathrm{~cm}$ treatment in August 2002.

Total macroalgal cover was significantly different among treatments for the last 3 survey dates (Table 2). Macroalgal cover in $40 \mathrm{~cm}$ treatments was significantly lower than controls in the latter half of the study. Survey data suggest a seasonal pattern in macroalgal cover, with values increasing in summer and decreasing in the winter. As with seagrass short-shoot values, macroalgal cover in $10 \mathrm{~cm}$ treatments recovered to control levels within the first year following the experimental disturbance (Fig. 4, Table 2). The spike in macroalgal cover on the September 2000 survey date was due to large amounts of drift algae, primarily Dictyota spp. and Laurencia spp., which had accumulated on the seagrass bank tops and in the excavations in particular.

Excavation treatment depths changed dramatically over time, with a roughly $50 \%$ decrease in depth in the 3 experimental treatments 3 mo after deployment (Fig. 5). In May 2001, 330 d after 


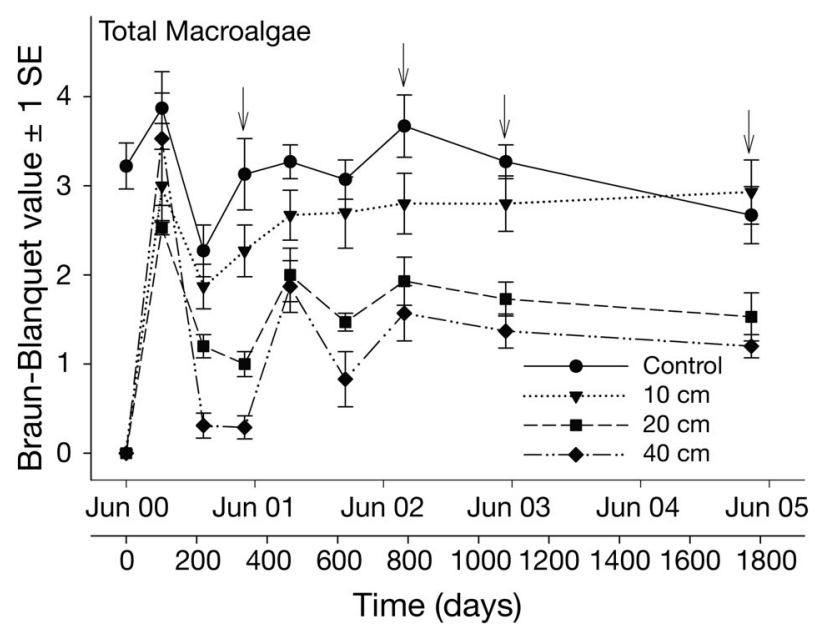

Fig. 4. Mean Braun-Blanquet cover values ( $\pm 1 \mathrm{SE}$ ) for the excavation experiments. Arrows indicate survey dates used in statistical analysis. $\mathrm{N}=5$ replicates per treatment

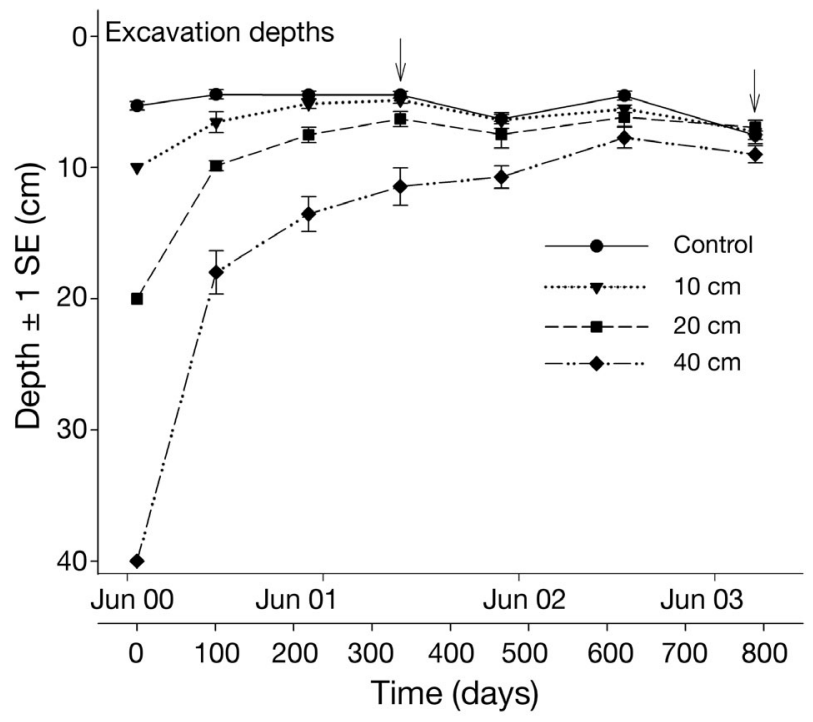

Fig. 5. Mean excavation experiment depths \pm 1 SE. Arrows indicate survey dates used in statistical analysis. $\mathrm{N}=5$ replicates per treatment

deployment, treatment still significantly impacted depth (Table 3), although only the $40 \mathrm{~cm}$ treatment was different from the control, $10 \mathrm{~cm}$, and $20 \mathrm{~cm}$ depths. In August 2002, 26 mo (780 d) after deployment, depth was not significantly different among treatments (Table 3).

\section{Fill experiment}

As in the excavation experiment, Thalassia testudinum fill and no-fill shoot counts were significantly lower than control counts during the May 2001 and
Table 3. ANOVA and Kruskal-Wallis results for excavation and fill experiment depths. Tests significant at the $\alpha=0.025$ level are indicated by asterisks. In the excavation experiment, May 2001 depths were natural-log transformed (LN depth) prior to analysis, while August 2002 depths were not

\begin{tabular}{|llrc|}
\hline Dependent variable & Date & F-value & p-value \\
\hline $\begin{array}{l}\text { Excavation experiment } \\
\text { LN depth }\end{array}$ & May 2001 & 17.77 & $<0.0001^{*}$ \\
$\begin{array}{l}\text { Depth } \\
\text { Fill experiment }\end{array}$ & Aug 2002 & 2.00 & 0.1264 \\
$\begin{array}{l}\text { Depth } \\
\text { Depth }\end{array}$ & & \\
& May 2001 & 9.92 & $0.0018^{*}$ \\
\hline
\end{tabular}

May 2002 surveys, 270 and 630 d after deployment (Table 4, Fig. 6). By May 2003, there was no longer a significant difference in shoot count (Table 4, Fig. 6). The lack of treatment effect persisted through April 2005, when mean shoot counts in all treatments were slightly higher than previously measured (Fig. 6), a result also observed in the excavation experiment (Fig. 3). Control T. testudinum shoot counts ranged from 202.7 to 295.0 shoots $\mathrm{m}^{-2}$ over the course of the experiment, with an overall mean of 242.7 shoots $\mathrm{m}^{-2}$ in the control treatments. In fill and no-fill treatments, shoot densities reached their highest levels in April 2005 , at 319.0 and 318.1 shoots $\mathrm{m}^{-2}$, respectively.

There were no significant differences in Syringodium filiforme shoot counts for the first year of the experiment (Table 4, Fig. 6). By May 2002, 630 d after the experiment was initiated, all treatments were significantly different from one another, with the no-fill treatment having the highest shoot counts and the control treatment having the lowest shoot counts (Fig. 6). This condition prevailed through May 2003, with treatments remaining significantly different from each other 990 d after deployment (Fig. 6). By April 2005, there were no longer significant differences among any of the treatments (Table 4). S. filiforme in the nofill treatment demonstrated the same compensatory recovery that was exhibited in the 20 and $40 \mathrm{~cm}$ treatments in the excavation experiment. Shoot counts of $S$. filiforme in the fill treatment also showed a significant increase over time, but the increase was not as dramatic as that of the no-fill treatments (Fig. 6). Interestingly, $S$. filiforme shoot counts in control treatments of the fill experiment were lower than control treatments of the excavation experiment, reflecting the patchiness of the seagrass habitat even at relatively small spatial scales $(<70 \mathrm{~m})$. Densities in the fill experiment controls ranged from 96.0 to 153.0 shoots $\mathrm{m}^{-2}$, with a mean of 122.4 shoots $\mathrm{m}^{-2}$. No-fill densities peaked at 1162.7 shoots $\mathrm{m}^{-2}$, about 10 times higher than control densities, in May 2002. Fill treatment den- 
Table 4. ANOVA results for fill experiment shoot counts and algal cover. Tests significant at the $\alpha=0.0125$ level (seagrass) and $\alpha=0.017$ level (macroalgae) are indicated by asterisks. Thalassia testudinum (SQRT TT) and Syringodium filiforme (SQRT SF) short-shoot counts were square-root transformed prior to analysis. Pairwise comparisons results are indicated in the right half of the table. Treatments with the same letter are not significantly different. $N=6$ replicates per treatment

\begin{tabular}{|c|c|c|c|c|c|c|}
\hline \multirow{2}{*}{$\begin{array}{l}\text { Dependent } \\
\text { variable }\end{array}$} & \multirow[t]{2}{*}{ Date } & \multirow{2}{*}{$\begin{array}{l}F / \chi^{2}- \\
\text { value }\end{array}$} & \multirow[t]{2}{*}{ p-value } & \multicolumn{3}{|c|}{ Pairwise comparisons } \\
\hline & & & & Control & Fill & No fill \\
\hline \multirow[t]{4}{*}{ SQRT TT } & May 2001 & 13.98 & $0.0005^{*}$ & A & B & B \\
\hline & May 2002 & 9.61 & $0.0021^{*}$ & $\mathrm{~A}$ & $\mathrm{~B}$ & $\mathrm{~B}$ \\
\hline & May 2003 & 1.51 & 0.2527 & $\mathrm{~A}$ & $\mathrm{~A}$ & $\mathrm{~A}$ \\
\hline & Apr 2005 & 0.22 & 0.8024 & $\mathrm{~A}$ & $\mathrm{~A}$ & $\mathrm{~A}$ \\
\hline \multirow[t]{4}{*}{ SQRT SF } & May 2001 & 2.94 & 0.0861 & $\mathrm{~A}$ & $\mathrm{~A}$ & $\mathrm{~A}$ \\
\hline & May 2002 & 26.32 & $<0.0001^{*}$ & $\mathrm{~A}$ & $\mathrm{~B}$ & $\mathrm{C}$ \\
\hline & May 2003 & 22.15 & $<0.0001^{*}$ & $\mathrm{~A}$ & $\mathrm{~B}$ & $\mathrm{C}$ \\
\hline & Apr 2005 & 3.89 & 0.0434 & $\mathrm{~A}$ & A & $\mathrm{A}$ \\
\hline \multirow[t]{3}{*}{ TMA } & May 2001 & 12.09 & $0.002^{*}$ & A & $\mathrm{B}$ & B \\
\hline & May 2003 & 11.01 & $0.004^{*}$ & A & $\mathrm{AB}$ & $\mathrm{B}$ \\
\hline & Apr 2005 & 9.43 & $0.009^{*}$ & $\mathrm{AB}$ & $\mathrm{A}$ & $\mathrm{B}$ \\
\hline
\end{tabular}
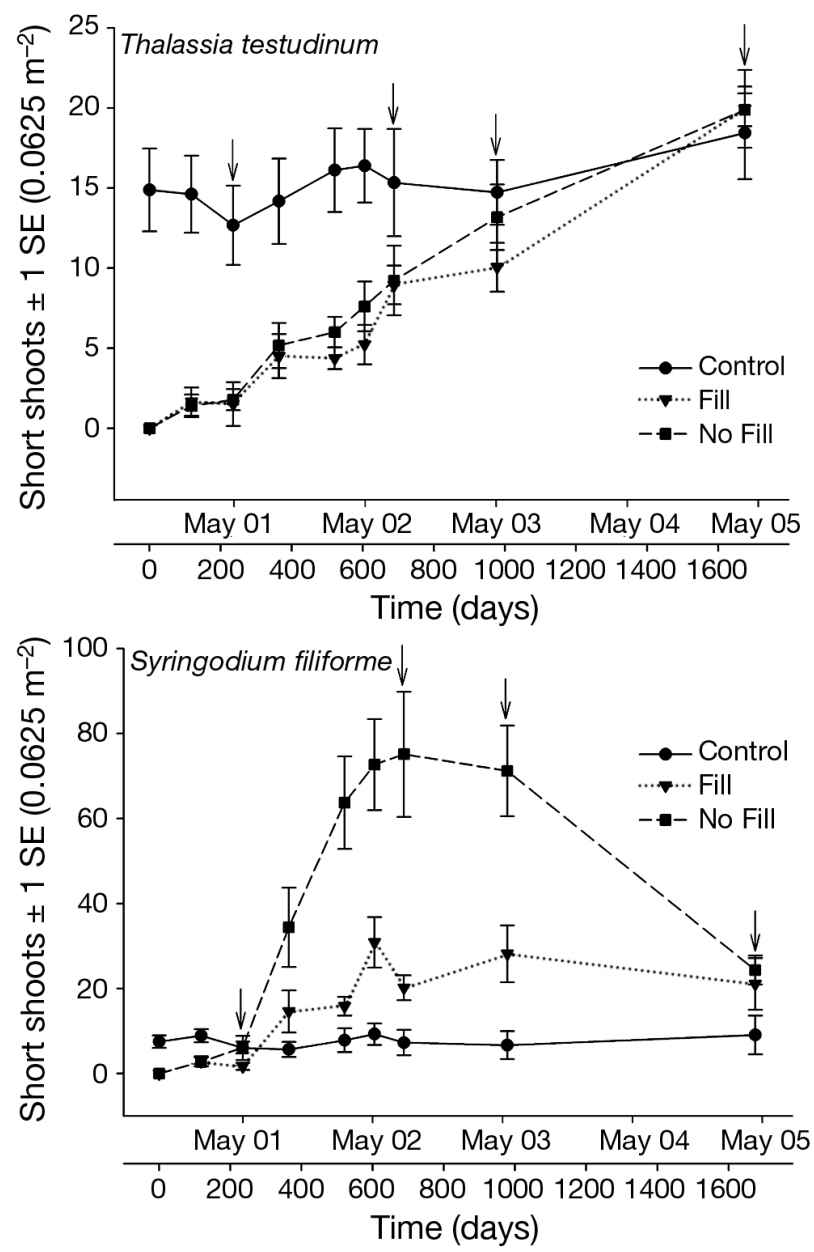

Fig. 6. Fill experiment. Mean Thalassia testudinum and Syringodium filiforme shoot counts $( \pm 1 \mathrm{SE}$ ) for all surveys. Survey dates selected for data analysis are indicated by arrows. $\mathrm{N}=6$ replicates per treatment sities also peaked in May 2002, with 493.3 shoots $\mathrm{m}^{-2}$.

Macroalgal cover in the fill treatments did not show as strong a seasonal signal as was exhibited in the excavation experiment (Figs. 4 \& 7). Like the deeper excavation treatments, the no-fill treatment continued to have significantly less macroalgae through the fifth year following the experimental disturbance (Table 4). In April 2005, the only significant differences were between the fill and no-fill treatments. The presence of the fill material appears to have inhibited macroalgal recovery in the first few years of the experiment (Fig. 7).

The depth of no-fill treatments in the fill experiment changed markedly in the first $120 \mathrm{~d}$ following deployment in September 2000, declining from a mean depth of $27.6 \mathrm{~cm}$ to $12.2 \mathrm{~cm}$. At no time did the fill treatment depths differ from controls (Table 3, Fig. 8), demonstrating that the fill material was not eroded away by water flow or compacted by its own weight. In fact, by August 2002, 690 d after deployment, there were no significant differences in depth among any treatments (Table 3). As with the 20 and $40 \mathrm{~cm}$ treatments in the excavation experiment, some time during the second year following deployment the no-fill treatment filled in, possibly due to both collapse of the margins into the disturbance and settling out of suspended sediment from the water column.

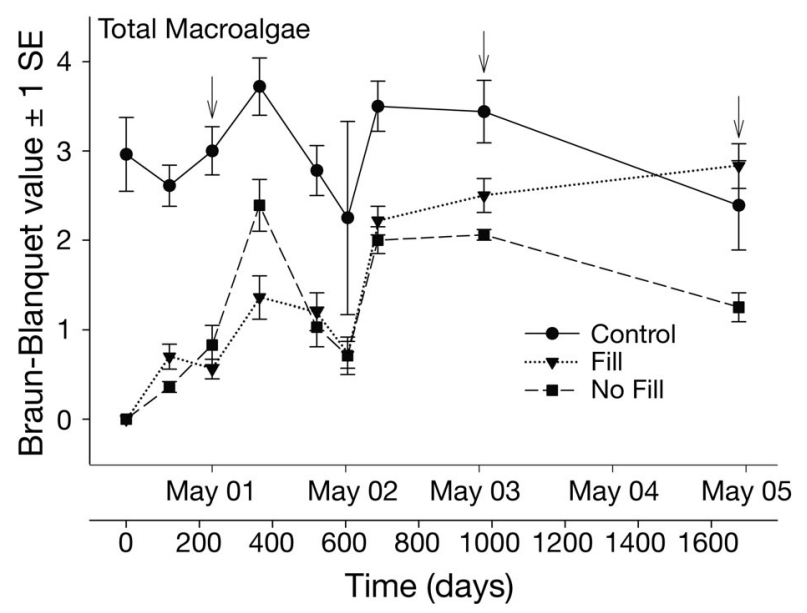

Fig. 7. Mean Braun-Blanquet cover values $( \pm 1 \mathrm{SE}$ ) for the fill experiments. Arrows indicate survey dates used in statistical analysis. $\mathrm{N}=6$ replicates per treatment except for total macroalgae surveys in May 2002, where $n=2$ replicates per treatment 


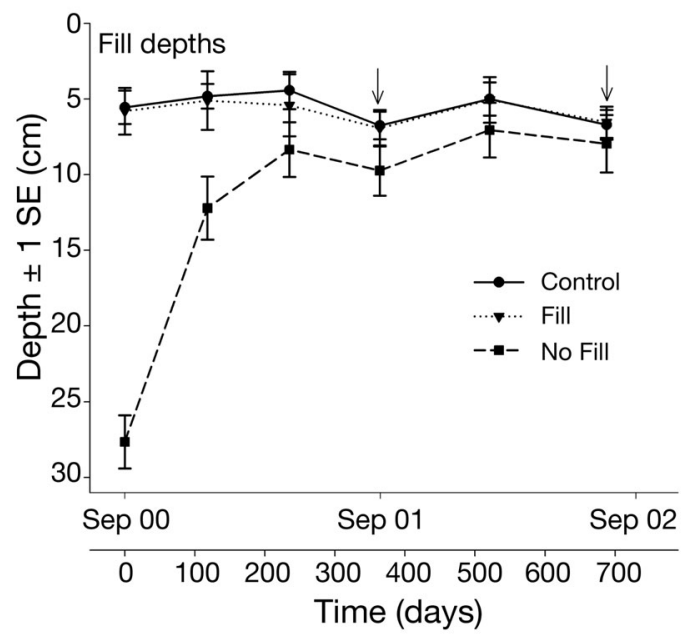

Fig. 8. Mean fill experiment depths \pm 1 SE. Arrows indicate survey dates used in statistical analysis. $\mathrm{N}=6$ replicates per treatment

\section{DISCUSSION}

Sediment excavation disturbances that exceeded $10 \mathrm{~cm}$ in depth had significant effects on short-shoot counts of Thalassia testudinum and Syringodium filiforme (Figs. $3 \& 6$ ). In the deepest excavations, T. testudinum short-shoot counts were significantly reduced for up to 2 yr; macroalgal cover was also reduced, and in the deepest excavations impacts to macroalgae persisted 5 yr after treatment (Figs. 4 \& 7). Although we observed T. testudinum seedlings in experimental plots during some surveys, recolonization of the disturbances by $T$. testudinum and $S$. filiforme was the result of vegetative propagation from excavation margins (Olesen et al. 2004). T. testudinum shoot density in all treatments increased to control levels between the second and third years following disturbance. S. filiforme shoot densities remained elevated in all deep $(>20 \mathrm{~cm})$ treatments in the May 2003 survey, and were still elevated in the $40 \mathrm{~cm}$ excavation treatments nearly $2 \mathrm{yr}$ later. Macroalgal recovery responded to treatments in a manner similar to that of $T$. testudinum, but with significant differences persisting in the deepest experimental treatments $(>20 \mathrm{~cm}) 5 \mathrm{yr}$ after the initial disturbance.

The response of Thalassia testudinum to treatment may be explained in part by its morphological characteristics. As much as 80 to $90 \%$ of the dry weight of T. testudinum is belowground biomass (Van Tussenbroek 1998, Kaldy \& Dunton 2000), and the belowground fraction may extend deeper than $1 \mathrm{~m}$ into the sediment (Marba et al. 1994). Shallow disturbances $(\leq 10 \mathrm{~cm})$ likely damaged very little of the belowground biomass and rhizome apical or basal shoot meristems and thus the experimental plots recovered quickly due to regrowth of intact short shoots. Deeper distur- bances, however, disrupted more of the belowground biomass, thereby severing rhizomes, damaging rhizome apical meristems, and removing the root-rhizomesediment matrix and nutrient reservoirs that underlay the meadow. Regrowth into deeper disturbances was slow because it required vegetative growth from the scar margins and/or recruitment of seedlings, processes that are dependent on low densities of horizontal meristems and seedlings and the slow rate of clonal growth of T. testudinum (Van Tussenbroek et al. 2000, Whitfield et al. 2004). Moreover, apical meristem tissue uncovered at the margins of the scar may be less likely to grow due to light exposure and may not possess the flexible rhizome architecture necessary to grow down into the remaining sediment (Marba et al. 1994, Duarte et al. 1997, Terrados 1997, Kenworthy et al. 2000). Somewhere between 10 and $20 \mathrm{~cm}$ appears to be a critical depth beyond which the damage to T. testudinum is such that recovery takes significantly longer.

The response of Syringodium filiforme to experimental manipulation was quite different from the response of Thalassia testudinum. Once all seagrass above- and belowground biomass was removed, the fast growth of $S$. filiforme conferred a short-term competitive advantage, and $S$. filiforme shoot densities quickly exceeded those of the surrounding, undisturbed seagrass bed, an overcompensation response observed in prior studies (Williams 1990, Fonseca et al. 2000). A 4- to 10-fold increase in shoot density of $S$. filiforme resulted in the deep unfilled treatments ( $\geq 20 \mathrm{~cm}$; Figs. $3 \& 6$ ). Williams (1987) reported a doubling of $S$. filiforme shoot density after clipping the aboveground biomass of $T$. testudinum in a mixed species seagrass bed in the Caribbean. In our study, an even greater increase in shoot density in deeper treatments was probably a result of not only increased light from above, but decreased competition for space in the substrate (Williams 1988, Duarte et al. 1998, 2000). During the third year of the study, we started to see a leveling off or decrease of $S$. filiforme shoot density in the deep unfilled treatments, and by the fifth year, $S$. filiforme counts returned to control levels in $20 \mathrm{~cm}$ excavations, fill, and no-fill plots, results that were similar to previous studies (Williams 1988, 1990, Kenworthy et al. 2002).

Macroalgal cover increased at about the same rate as Thalassia testudinum, but unlike $T$. testudinum, remained significantly reduced in deeper experimental treatments 5 yr after the start of the study. Macroalgae form the understory in the seagrass-coral communities on the bank tops, but to our knowledge no one has studied the ecosystem function of macroalgae in this habitat. Certain species may act to entrain T. testudinum seedlings (Whitfield 2002) and also contribute to substrate stabilization (pers. obs.). Rhizophytic algae facilitate seagrass recolonization of denuded sub- 
strates (Williams 1990); thus, the slower recovery of T. testudinum in the deeper experimental treatments may have been correlated to the slower recovery of macroalgae in those same plots.

Results from the fill treatment suggest that pea rock may have affected Syringodium filiforme and Thalassia testudinum in different ways. After $1 \mathrm{yr}, S$. filiforme fill treatment shoot counts were still less than half that of no-fill plots (Fig. 6). Thus, the pea rock may have ameliorated the overcompensation response of $S$. filiforme that we observed in the excavation experiment and in the no-fill treatment. In the early stages of recovery in the fill and excavation experiments, the faster growth of $S$. filiforme enabled it to capitalize on space not yet inhabited by $T$. testudinum, whereas in the fill treatments, this effect may not have been as great due to the nutrient-poor substrate and mechanical inhibition by the relatively coarse pea rock. Macroalgal recovery also appears to have been slowed by the presence of fill material in the first few years of the experiment. T. testudinum may have been at an advantage in colonizing the sterile fill material due to a higher degree of clonal integration and less reliance on nutrients in the experimental substrate (Tomasko \& Dawes 1989).

Our findings have implications for seagrass restoration. Without intervention, Thalassia testudinum shoot counts in our experimental treatment reached control levels in 33 to 36 mo regardless of disturbance depth. This recovery estimate concurs with previous studies on $T$. testudinum recovery in propeller scars (Zieman 1976, Dawes et al. 1997, Kenworthy et al. 2002). Our results demonstrate that disturbance effects on nonclimax species may persist even though $T$. testudinum shoot counts have reached ambient densities. The same successional revegetation process described by Williams (1990) took place in our plots. Yet 5 yr after the disturbance, community structure had not been restored to an undisturbed state, likely affecting ecosystem function as well.

\section{CONCLUSION}

Based on the results of this study, we conclude that: (1) Thalassia testudinum is more sensitive to disturbance depth than Syringodium filiforme, and (2) use of pea rock does not inhibit the recovery of the climax species $T$. testudinum into the experimental disturbances. An important factor that was not addressed in our study is the vulnerability of disturbances to further erosion. Storms can have dramatic and lasting impacts on seagrass beds (Preen et al. 1995), especially when there is existing motor vessel damage (Whitfield et al. 2002). Until a new root-rhizome-sediment matrix is established by the regrowth of seagrass into the unvegetated area, the unconsolidated sediment is susceptible to erosion (Zieman 1976, Sargent et al. 1995, Whitfield et al. 2002). Based on our results and observations, regrading disturbances with native limestone pea rock would leave them less susceptible to storminduced erosion and allow for seagrass recovery.

Once an anthropogenic disturbance occurs, few techniques for intervention exist beyond stopping the impact and waiting for natural recolonization (Hawkins et al. 1999). When prevention fails, cost-effective, easily implemented techniques must be found for restoration of marine ecosystems and the services they provide. Ideally these interventions should provide for not only the short-term return of ecosystem function, but also the long-term resiliency of the system to withstand future perturbations (Moberg \& Rönnbäck 2003).

Acknowledgements. This project was funded by the National Oceanic and Atmospheric Administration (NOAA) Damage Assessment Center, the Office of National Marine Sanctuaries, NOAA, and the Center for Coastal Fisheries and Habitat Research. We thank the following people for assistance with the field surveys: C. Bonn, K. Kirsch, S. Meehan, A. Schwarzschild, and A. Uhrin. Comments by G. Dayton, G. Di Carlo, P. Hay, C. Richmond, and 3 anonymous reviewers greatly improved this manuscript.

\section{LITERATURE CITED}

Campbell ML, Paling EI (2003) Evaluating vegetative transplant success in Posidonia australis: a field trial with habitat enhancement. Mar Pollut Bull 46:828-834

Costanza R, d'Arge R, De Groot R, Fraber S and 9 others (1997) The value of the world's ecosystem services and natural capital. Nature 387:253-260

Creed JC, Filho GMA (1999) Disturbance and recovery of the macroflora of a seagrass (Halodule wrightii Ascherson) meadow in the Abrolhos Marine National Park, Brazil: an experimental evaluation of anchor damage. J Exp Mar Biol Ecol 235:285-306

Dawes CJ, Andorfer J, Rose C, Uranowski C, Ehringer N (1997) Regrowth of the seagrass Thalassia testudinum into propeller scars. Aquat Bot 59:139-155

Duarte CM (2002) The future of seagrass meadows. Environ Conserv 29:192-206

Duarte CM, Terrados J, Agawin NSR, Fortes MD, Bach S, Kenworthy WJ (1997) Response of a mixed Philippine seagrass meadow to experimental burial. Mar Ecol Prog Ser 147: 285-294

Duarte CM, Merino M, Agawin NSR, Uri J, Fortes MD, Gallegos ME, Marba N, Hemminga MA (1998) Root production and belowground seagrass biomass. Mar Ecol Prog Ser 171: 97-108

Duarte CM, Terrados J, Agawin NSR, Fortes MD (2000) An experimental test of the occurrence of competitive interactions among SE Asian seagrasses. Mar Ecol Prog Ser 197: $231-240$

Dunton KH, Schonberg SV (2002) Assessment of propeller scarring in seagrass beds of the south Texas coast. J Coast Res 37:100-110

Durako MJ, Hall MO, Sargent F, Peck S (1992) Propeller scars in seagrass beds: an assessment and experimental study of 
recolonization in Weedon Island State Preserve, Florida. In: Webb FJ Jr (ed) Proc 19th Annu Conf Wetlands Restoration and Creation. Hillsborough Community College, FL, p 42-53

Fonseca MS, Kenworthy WJ, Courtney FX, Hall MO (1994) Seagrass planting in the southeastern United States: methods for accelerating habitat development. Restor Ecol 2: $198-212$

Fonseca MS, Julius BE, Kenworthy WJ (2000) Integrating biology and economics in seagrass restoration: How much is enough and why? Ecol Eng 15:227-237

Fonseca MS, Whitfield PE, Kenworthy WJ, Colby DR, Julius BE (2004) Use of two spatially explicit models to determine the effect of injury geometry on natural resource recovery. Aquat Conserv 14:281-298

Fourqurean JW, Willsie A, Rose CD, Rutten LM (2001) Spatial and temporal pattern in seagrass community composition and productivity in South Florida. Mar Biol 138:341-354

Green EP, Short FT (2003) World atlas of seagrasses. University of California Press, Berkeley, CA

Hastings K, Hesp P, Kendrick GA (1995) Seagrass loss associated with boat moorings at Rottnest Island, Western Australia. Ocean Coast Manag 26:225-246

Hawkins SJ, Allen JR, Bray S (1999) Restoration of temperate marine and coastal ecosystems: nudging nature. Aquat Conserv 9:23-46

Kaldy JE, Dunton KH (2000) Above- and below-ground production, biomass and reproductive ecology of Thalassia testudinum (turtle grass) in a subtropical coastal lagoon. Mar Ecol Prog Ser 193:271-283

Kenworthy WJ, Fonseca MS (1992) The use of fertilizer to enhance growth of transplanted seagrasses Zostera marina L. and Halodule wrightii Aschers. J Exp Mar Biol Ecol 163: 141-161

Kenworthy WJ, Fonseca MS, Whitfield PE, Hammerstrom KK, Schwarzschild AC (2000) A comparison of two methods for enhancing the recovery of seagrasses into propeller scars: mechanical injection of a nutrient and growth hormone solution vs. defecation by roosting seabirds. Final report to the Florida Keys Restoration Trust Fund, Tavernier, FL

Kenworthy WJ, Fonseca MS, Whitfield PE, Hammerstrom KK (2002) Analysis of seagrass recovery in experimental excavations and propeller-scar disturbances in the Florida Keys National Marine Sanctuary. J Coast Res 37:75-85

Kirsch KD, Barry KA, Fonseca MS, Whitfield PE, Meehan SR, Kenworthy WJ, Julius BE (2005) The mini-312 program: An expedited damage assessment and restoration process for seagrasses in the Florida Keys National Marine Sanctuary. J Coast Res 40:109-119

Marba N, Gallegos ME, Merino M, Duarte CM (1994) Vertical growth of Thalassia testudinum: seasonal and interannual variability. Aquat Bot 47:1-11

Milazzo M, Badalamenti F, Ceccherelli G, Chemello R (2004) Boat anchoring on Posidonia oceanica beds in a marine protected area (Italy, western Mediterranean): effect of anchor types in different anchoring stages. J Exp Mar Biol Ecol 229: $51-62$

Moberg F, Rönnbäck P (2003) Ecosystem services of the tropical seascape: interactions, substitutions and restoration. Ocean Coast Manag 46:27-46

Olesen B, Marba N, Duarte CM, Savela RS, Fortes MD (2004) Recolonization dynamics in a mixed seagrass meadow: the role of clonal versus sexual processes. Estuaries 27: $770-790$

Patriquin D (1973) Estimation of growth rate, production and age of the marine angiosperm Thalassia testudinum König. Caribb J Sci 13:111-123

Editorial responsibility: Kenneth Heck (Contributing Editor), Dauphin Island, Alabama, USA
Powell GVN, Fourqurean JW, Kenworthy WJ, Zieman JC (1991) Bird colonies cause seagrass enrichment in a subtropical estuary: observational and experimental evidence. Estuar Coast Shelf Sci 32:567-579

Prager EJ, Halley RB (1999) The influence of seagrass on shell layers and Florida Bay mudbanks. J Coast Res 15: 1151-1162

Preen AR, Lee Long WJ, Coles RG (1995) Flood and cyclone related loss, and partial recovery, of more than $1000 \mathrm{~km}^{2}$ of seagrass in Hervey Bay, Queensland, Australia. Aquat Bot 52:3-17

Rodriguez RW, Webb RMT, Bush DM (1994) Another look at the impact of Hurricane Hugo on the shelf and coastal resources of Puerto Rico, USA. J Coast Res 10:278-296

Sargent FJ, Leary TJ, Crewz SW, Kruer CR (1995) Scarring of Florida's seagrasses: assessment and management. Florida Mar Res Inst Tech Rep TR-1, Florida Marine Research Institute, St. Petersburg, FL

Short FT, Wyllie-Echeverria S (1996) Natural and humaninduced disturbance of seagrasses. Environ Conserv 23: $17-27$

Terrados J (1997) Is light involved in the vertical growth response of seagrasses when buried by sand? Mar Ecol Prog Ser 152:295-299

Tomasko DA, Dawes CJ (1989) Evidence for physiological integration between shaded and unshaded short shoots of Thalassia testudinum. Mar Ecol Prog Ser 54:299-305

Uhrin AV, Holmquist JG (2003) Effects of propeller scarring on macrofaunal use of the seagrass Thalassia testudinum. Mar Ecol Prog Ser 250:61-70

Underwood AJ (1997) Experiments in ecology: their logical design and interpretation using analysis of variance. Cambridge University Press, Cambridge

Van Keulen M, Paling EI, Walker CJ (2003) Effect of planting unit size and sediment stabilization on seagrass transplants in western Australia. Restor Ecol 11:50-55

Van Tussenbroek BI (1998) Above- and below-ground biomass and production by Thalassia testudinum in a tropical reef lagoon. Aquat Bot 61:69-82

Van Tussenbroek BI, Galindo CA, Marquez J (2000) Dormancy and foliar density regulation in Thalassia testudinum. Aquat Bot 68:281-295

Walker DI, Lukatelich RJ, Bastyan G, McComb AJ (1989) Effect of boat moorings on seagrass beds near Perth, Western Australia. Aquat Bot 36:69-77

Whitfield PE (2002) Recruitment, survival and growth of Thalassia testudinum seedlings in physically disturbed seagrass beds. MSc thesis, University of North Carolina, Wilmington, NC

Whitfield PE, Kenworthy WJ, Hammerstrom KK, Fonseca MS (2002) The role of a hurricane in the expansion of disturbances initiated by motor vessels on seagrass banks. J Coast Res 37:86-99

Whitfield PE, Kenworthy WJ, Durako MJ, Hammerstrom KK, Merello MF (2004) Recruitment of Thalassia testudinum seedlings into physically disturbed seagrass beds. Mar Ecol Prog Ser 267:121-131

Williams SL (1987) Competition between the seagrasses Thalassia testudinum and Syringodium filiforme in a Caribbean lagoon. Mar Ecol Prog Ser 35:91-98

Williams SL (1988) Disturbance and recovery of a deepwater Caribbean seagrass bed. Mar Ecol Prog Ser 42:63-71

Williams SL (1990) Experimental studies of Caribbean seagrass bed development. Ecol Monogr 60:449-469

Zieman JC (1976) The ecological effects of physical damage from motor boats on turtle grass beds in southern Florida. Aquat Bot 2:127-139 